\title{
A fogpótláskészítés szempontjai biszfoszfonáttal kezelt idős páciens esetén
}

\author{
Bata Zsófia dr. - Vasziné Szabó Enikő dr. - Tóth Zsuzsanna dr. \\ Semmelweis Egyetem, Fogorvostudományi Kar, Konzerváló Fogászati Klinika, Budapest
}

\begin{abstract}
Napjainkra egyre elterjedtebbek a csont átépülésére, vérkeringésére és homeosztázisára ható gyógyszerek, amelyek szerepe megkérdőjelezhetetlen számos súlyos betegség terápiájában. Ilyenek például a biszfoszfonátok és más antireszorptív és antiangiogenikus terápiás szerek. Pontos anamnézisfelvételt követően minden fogorvosi praxisban detektálható, hogy az ezeket a gyógyszereket szedô páciensek száma emelkedik. Célunk egy idős nóbeteg komplex fogászati kezelésén bemutatva megvilágosítani azokat a prevenciós lépéseket, amelyek betartásával minimalizálható a rizikócsoportba tartozó betegekben a gyógyszer indukálta osteonecrosis kialakulásának valószínúsége. A szájsebészeti, konzerváló fogászati és protetikai ellátás szinkronizálása kitüntetett szereppel bír egy idős, sok háttérbetegséggel rendelkező páciens esetén. Célunk továbbá felhívni a társszakmákban dolgozó kollégák figyelmét a beavatkozások időzítésének jelentőségére. Az állcsontnecrosis megelózésének alapja a gyógyszerszedés előtti teljes körú fogászati szanálás. Amennyiben azonban a páciens már szedi a csontmetabolizmusra ható és mucotoxicus készítményt, megfelelő felkészültség és gondosság mellett lehet esély a súlyos, az életminőséget komolyan befolyásoló és rossz gyógyulási hajlamot mutató szövődmények megelőzésére.
\end{abstract}

Orv Hetil. 2018; 159(48): 2031-2036.

Kulcsszavak: gyógyszer indukálta osteonecrosis az állcsontban, biszfoszfonát, komplex fogászati rehabilitáció, prevenció, rizikópáciens

\section{Considerations of elderly patient's dental rehabilitation treated with bisphophonate}

Recently, drugs targeting the remodelling, vascular circulation and homeostasis of bone are frequently applied with an unquestionable benefit in the therapy of numerous severe medical conditions. Besides bisphosphonates, other antiresorptive and antiangiogenic drugs are also used, however, limited publications are focusing on data of their results. Increasing number of patients arrives the mentioned medication is increasing in the daily dental practice, especially when accurate anamnesis is taken. Our aim is to highlight the preventive considerations that help minimize the occurence of medication-related osteonecrosis of the jaw by presentating a complex dental rehabilitation of a patient at risk. The synchronization of dental surgery, conservative and prosthodontic treatment is essential in the case of an elderly patient having many concomitant disorders. Our aim is also to draw the attention of our colleagues working on different medical fields to the timing of dental procedures. The best and simplest way to prevent jaw necrosis is to achieve good oral health and hygiene before the introduction of antiresorptive therapy. If, however, our patient is already taking this medication, we still have a chance to prevent the appearance of this devastating condition by following the preventive measures. The medication-related necrosis of the jaw is a severe condition leading to a decreased life quality and having a reduced healing expectancy.

Keywords: medication-related osteonecrosis of the jaw, bisphosphonate, complex dental rehabilitation, prevention, risk patient

Bata Zs, Vasziné Szabó E, Tóth Zs. [Considerations of elderly patient's dental rehabilitation treated with bisphophonate]. Orv Hetil. 2018; 159(48): 2031-2036.

(Beérkezett: 2018. május 29.; elfogadva: 2018. július 7.)

A cikk anyagából „EADPH 2016 Dental rehabilitation of an elderly patient treated with bisphosphonates” címmel poszter előadás készült. 


\section{Rövidítések}

$\mathrm{BP}=$ biszfoszfonát; $\mathrm{BRONJ}=($ bisphosphonate-related osteonecrosis of the jaw) biszfoszfonát indukálta állcsontnecrosis; EDTA $=$ etilén-diamin-tetraecetsav; FDI $=($ Federation Dentaire Internationale) Nemzetközi Fogászati Társaság; MRONJ $=($ medication-related osteonecrosis of the jaw $)$ gyógyszer indukálta állcsontnecrosis; RANK-L = (receptor activator of nuclear factor kappa B ligand) receptoraktivátor nukleáris faktor kappa-B-ligandja

$\mathrm{Az}$ állcsontok osteonecrosisának kialakulásában a biszfoszfonátok (BP) mellett az egyéb antireszorptív (denoszumab) és antiangiogenikus (RANK-L-inhibitor) terápiás szerek is fontos szerepet játszhatnak. Ez vezetett a nómenklatúra megváltozásához, a korábban használatos BRONJ (bisphosphonate-related osteonecrosis of the jaw) kifejezés helyett 2014-tól a MRONJ (medicationrelated osteonecrosis of the jaw) rövidítés használatos [1].

A gyakorló fogorvos számára ez azt jelenti, hogy bővült a rizikóbetegek köre. Ezen gyógyszerek szedése a csontlebontást csökkenti, míg a csontok denzitása nő, ezáltal hat a csontok átépülésére [2]. Antiangiogenikus szupportív terápia mellett és zoledronsav esetében a csontok vérellátása rosszabb [3]. Az aminobiszfoszfonátok az epithelialis sejtek proliferációs rátáját negatívan befolyásolják, illetve direkt mucotoxicus hatásuk is ismert [4]. A MRONJ patofiziológiájában fontos szerepet játszik a gyulladás, illetve a fertőzés, amely mikro- vagy makrotraumákon keresztül okoz necrosist [5].

Ezeket a gyógyszereket széles körben alkalmazzák különböző csontanyagcsere-betegségekben - például posztmenopauzális osteoporosis, Paget-kór, osteogenesis imperfecta, osteopenia, fibrosus dysplasia, súlyos hypercalcaemia, rheumatoid arthritishez társuló osteoporosis, myeloma multiplex - és malignus tumorok (emlő, prostata, tüdő, hólyag, vese, pajzsmirigy) csontmetasztázisa kialakulásának megakadályozására, illetve metasztázis esetén fájdalomcsillapításra. Ismert e szerek direkt apoptotikus hatása a daganatos sejtekre. Csökkentik a patológiás törések számát, javítják a csont teherbíró képességét. E szerek célzottan rendkívül effektívek. Használatuk nem kerülhető el [6].

A pozitív tulajdonságok mellett számos mellékhatásuk is ismert, például gastrointestinalis intolerancia (hányinger, hányás, hasmenés), nyelőcsőgyulladás és -fekély, illetve ennek progressziója, ízületi, csont- és izomfájdalom, allergiás reakciók, akut veseelégtelenség és a krónikus veseelégtelenség akcelerálódása. Osteonecrosis a szájüregben fordul elő a leginkább. Ezt a szövődményt Marx írta le először 2003-ban [7].

A csontnecrosis kialakulásának veszélye nó, ha az alkalmazás módja intravénás, és a terápia intenzív (havi). Szájon keresztül, illetve szubkután adagolás esetén is kialakulhat, ha az éveken keresztül tart $[8,9]$. Az osteoporosis kezelésekor azonban alacsonyabb a rizikó, mint az onkológiai esetekben kezelt betegeknél [10]. Nő a MRONJ incidenciája a gyógyszerek alkalmazási idejének hosszabbodásával [11].

\section{Esetismertetés}

\section{Anamnézis}

A Semmelweis Egyetem Konzerváló Fogászati Klinikáján 2014-ben jelentkezett 86 éves nőbetegünk, a bal felső régióból kiinduló akut panasszal, fájdalommal. Osteoporosisát 5 éve diagnosztizálták, azóta kezelik iv. zoledronsav (Aclasta $5 \mathrm{mg}$; Novartis Pharma $\mathrm{GmbH}$, Bázel, Svájc) készítménnyel, amelyet eddig összesen négy alkalommal kapott, utoljára 16 hónapja. Maculadegeneráció miatt többszöri szemműtéten esett át, látása korlátozott. Csípőprotézis-beültetés történt 2013-ban, járása nehézkes, segédeszközt igényel. Kétszer, 1976ban és 1987-ben szívinfarktuson esett át, azóta thrombocytaaggregáció-gátlót, acetilszalicilsavat (ASA Protect, 100 mg/nap; PharmaSwiss Ceska Republika, Prága, Csehország) és szelektív béta-receptor-blokkolót (Metoprolol Z Hexal 100 mg; Sandoz Hungária, Budapest) szed. Magasvérnyomás-betegségét gyógyszeresen tartják karban (Valsartan-Teva 160 mg, Teva Gyógyszergyár, Budapest). Pajzsmirigyét 1989-ben eltávolították, emiatt L-tiroxin-szubsztitúcióban részesül. Asthma bronchiale miatt Symbicort (budezonid, formoterol; AstraZeneca AB, Södertälje, Svédország) inhalálót alkalmaz. Fogászati ellátását igazolt lidokain- és penicillinallergiája is befolyásolta. Extraoralis és temporomandibularis ízületi vizsgálata, valamint sztomatoonkológiai szürése során kóros elváltozás nem volt tapasztalható.

\section{Fogászati status}

A felső állcsonton körülbelül 20 éves, 12 tagból álló, a 14-es, 13-as, 11-es, 21-es, 24-es és 25-ös fogakon elhorgonyzott hídpótlást viselt. A fogak az FDI (Federation Dentaire Internationale) szerint kerültek megszámozásra. A koronák nem megfelelő illeszkedése miatt jelentős dentálisplakk-felhalmozódás és következményes ínygyulladás volt megfigyelhető. A 25-ös fog diagnózisa: fogágyeredetü fogbélgyulladás (1. ábra).

Az alsó fogatlan állcsont mélyült negatív, kettős gerincéllel rendelkezik. Az ugyancsak körülbelül 20 éves, teljes kivehető akrilát fogpótlás csekély retenciójára panaszkodott a páciens (1. ábra).

\section{Radiológiai vizsgálat}

A klinikai vizsgálat után panorámaröntgen- és intraoralis felvételek készültek. A felső állcsonton generalizált krónikus fogágygyulladás látható. A mandibula a fogmedernyúlvány bázisán túl már az állkapocstestre kiterjedően is leépült (2. ábra). Az intraoralis felvételek a rosszul illesz- 


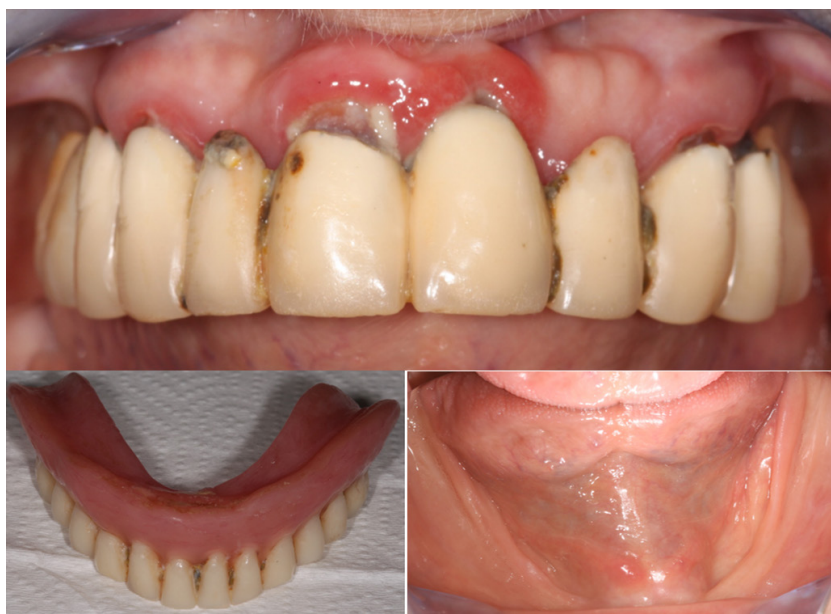

1. ábra

Preoperatív fotók az alsó és felső állcsontról és a teljes kivehetô alsó akrilátlemezes fogpótlásról

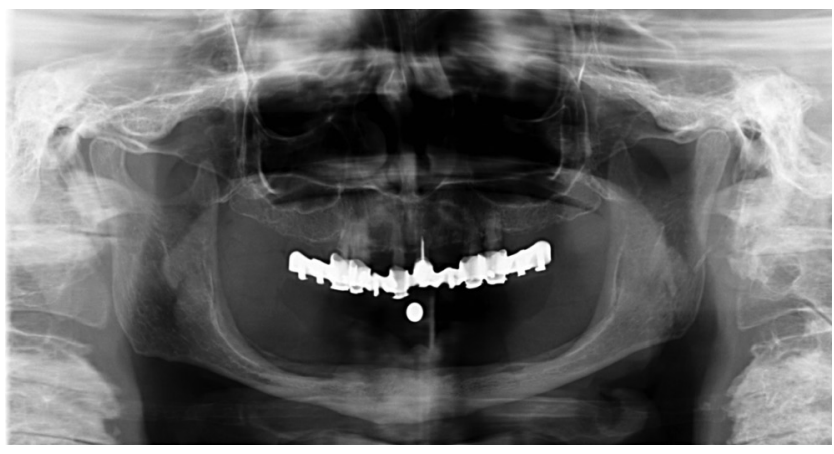

2. ábra

Kiindulási panorámaröntgen-felvétel. Jól látható a bázisáig le épült mandibula

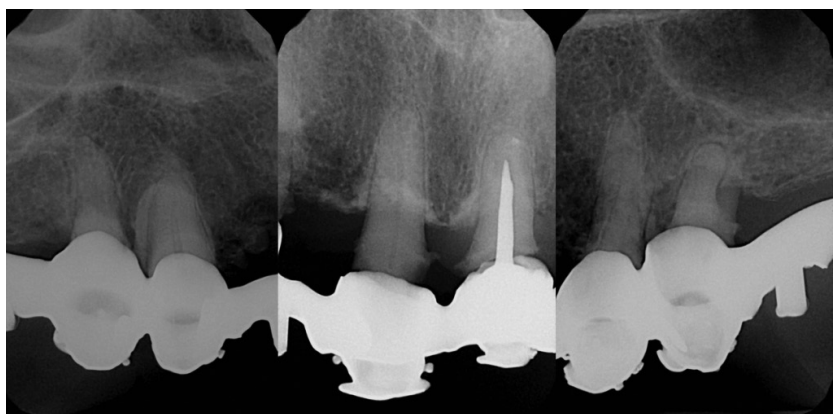

3. ábra

A kiindulási status röntgenfelvételei. Balról jobbra a fogak: 14, $13,11,21,24,25$

kedő felső fogpótlás mellett a beszűkült gyökércsatornájú gyökereket, valamint a 25-ös fog súlyos fogágygyulladását mutatják (3. ábra).

\section{A kezelési tervet befolyásoló tényezők}

Olyan fogpótlást kell tervezni, amely rossz vizuális kontroll esetén is könnyen tisztítható. A biszfoszfonátadagolás lehetséges szövődménye az osteonecrosis. Ennek elkerülése érdekében a traumatikus beavatkozások számának csökkentésére kell törekedni, ezek a dentoalveo- laris sebészi beavatkozások ugyanis a csontnecrosis legfóbb kiváltó okai [12].

Amennyiben a fogeltávolítás elkerülhetetlen, azt minimálinvazív módon kell kivitelezni, antibiotikumvédelemben. A maradék fogak megtartása abban az esetben is megfontolandó, ha a készülő fogpótlás elhorgonyzásában nem játszanak szerepet. A gyökérkezelt radixok az 'overdenture' típusú fogsor megtámasztására és a fogmedernyúlvány megőrzésére is alkalmasak. Az így megtartott állcsontgerinc a kivehető fogpótlás retenciója szempontjából is előnyösebb. Az irodalom szerint gyökérkezelés közben a gyökércsúcson túlpréselődő fogtörmelék fertőzöttnek tekinthető, és bakteriális infiltrációt okozhat [13]. A fertőzött fogakból fooleg Actinomycesfajokat lehet kitenyészteni [14]. Emiatt páciensünk esetében is antibiotikum szedése volt indikált a gyökérkezelés során a munkahossz meghatározásáig, de ismert penicillinallergiája miatt a másodlagosan választandó szert, a klindamicint (300 mg) kapta profilaxisként. Az adagolás a következők szerint történt: profilaxisként a fogkő-eltávolítás és a gyökérkezelések esetén a munkahossz meghatározásáig 1 órával a beavatkozás előtt $(600$ $\mathrm{mg}$ ), védelemben pedig 2 nappal a foghúzás előtt kezdve és még 1 hétig a beavatkozás után $(4 \times 300 \mathrm{mg})$ a Magyar Orvostársaságok és Egyesületek Szövetségének ajánlása alapján [15].

Esetünkben fokozottan törekedtünk az ülések számának minimalizálására (lehetőség szerint egy ülésben több fog kezelése) az antibiotikumterhelés és a mozgásszervi panaszok miatti fizikális igénybevétel csökkentése érdekében. Mivel az antibiotikumvédelem kialakulásához minimum 2 nap szükséges, a panaszos 25-ös fog gyulladt fogbelét antibiotikumprofilaxisban eltávolítva az akut panaszokat megszüntettük a foghúzásig. A páciens ezzel megkezdte a 9 napos antibiotikumkúrát. Amíg a védelem kialakult, megvalósult a maradék fogak professzionális tisztítása és gyökérkezelése.

Mi okozza a nehézséget a rizikócsoportba tartozó páciensek fogpótlásának tervezésekor?

Bizonyos foghiányok esetén a komfortosabb rögzített fogpótlás nem készíthető. A csökkent oszteointegráció miatt viszont az implantáció a rizikócsoportba tartozó páciensek esetében kontraindikált [16], tehát csak kivehető fogpótlás tervezhető. A kivehető fogpótlásnak a nyálkahártyára gyakorolt nyomása és a baktériumok és gombák megtelepedése viszont predesztinál az osteonecrosisra. A puhán maradó anyagok megoldást jelenthetnének a nyomáscsökkentésre $[17,18]$, de ezek felületén könnyen akkumulálódik a szájüregi flóra [19], és kihordási idejük is erősen korlátozott a csökkent szakítóés nyírószilárdság miatt $[20,21]$.

\section{Kezelési terv}

A kezelési terv elsődleges lépése a supra- és subgingivalis fogkő-eltávolítás, polírozás, gyökérfelszín-simítás, instruálás és motiválás. A régi fogpótlás eltávolítását és a ke- 
zelések idejére ideiglenes híd készítését terveztük. A következő lépés a 14-es, 13-as, 11-es, 21-es, 24-es fogak gyökérkezelése abszolút izolálásban és antibiotikumos profilaxisban és a 25-ös fog minimálinvazív eltávolítása antibiotikumvédelemben. A funkcionálisan helyreállíthatatlan gyökérkezelt fogakra öntöttfém csapos sapkás lezárást és a felső állcsontra dentomucosalis megtámasztású akrilát alaplemezes 'overdenture' típusú fogsort terveztünk. Az alsó állcsonton új, teljes kivehető akrilát alaplemezes fogpótlás készítését indikáltuk.

\section{A kezelés folyamata}

Jól kialakított szájhigiénével és a szájöblítők rendszeres használatával a patogén baktériumok száma redukálható [22]. Így csökken a valószínúsége az esetleges mikrotraumák miatti bakteriális infiltrációnak és a következményes irreverzibilis elváltozások kialakulásának. Cousido és mtsai javaslata alapján minden fogászati beavatkozás előtt 1 perces 0,2\%-os klórhexidines (Corsodyl; GlaxoSmithKline Magyarország, Budapest) szájöblítést végeztettünk a beteggel [23].

A gyökérkezeléseket helyi érzéstelenítésben (Ultracain DS Forte; Sanofi-Aventis, Párizs, Franciaország), abszolút izolálásban (Kofferdam) végeztük. Korábban beszámoltak Kofferdam kapocs okozta trauma lehetséges induktív hatásáról a MRONJ kialakulásában, emiatt a Kofferdam kapocs felhelyezése fokozott gondossággal, néhány csonkon a retenciós felszín preparálásával történt. A biológiai szélesség megóvása rendkívül fontos. Ismert a biszfoszfonátok mucotoxicitasa. Ez is kiinduló pontja lehet az osteonecrosisnak [24].

Peters és mtsai ajánlása alapján, a Kofferdam felhelyezése után a fogakat és a gumilepedőt $80 \%$-os etanololdattal 2 percig fertőtlenítettük [25]. A fogak gyökérkezelését 'step back' technikával végeztük. A 21-es fog revíziója során a régi gyökértömést oldószer nélkül, mechanikailag távolítottuk el. A munkahosszokat elektromos apexlokátor segítségével (Raypex5; VDW GmbH, München, Németország) és ellenőrző tüs röntgenfelvétellel határoztuk meg (4. ábra). A gyökércsatornák átöblítésére 2,5\%-os nátrium-hipoklorit oldatot, a 'smear layer' eltávolítására 17\%-os EDTA (etilén-diamin-tetraecetsav) oldatot, köztes átöblítésként steril desztillált vizet, a tágítás befejeztével 1 percig a teflonnal lezárt csatornákban Solumium Dental (Solumium Kft., Budapest) oldatot használtunk. A gyökérkezelések és az újra-gyökérkezelés (21-es fog) összesen két ülésben lezajlottak. A két ülés között a fogak kalcium-hidroxid és üvegionomer cementtel történő $\left(\operatorname{Ketac}^{\mathrm{TM}}\right.$ Molar; 3M ESPE, St. Paul, MN, Amerikai Egyesült Államok) lezárással és ideiglenes hídpótlás (Dentalon® Plus; Heraeus Kulzer, Hanau, Németország) rögzítésével kerültek ellátásra. A gyökértömés papírpoénnal kiszárított csatornákba, lateralis kondenzációs technikával készült gyökértömő paszta (AH Plus®; DeTrey, Konstanz, Németország) és Guttapercha csúcsok (DiaDent Europe B.V., Almere,

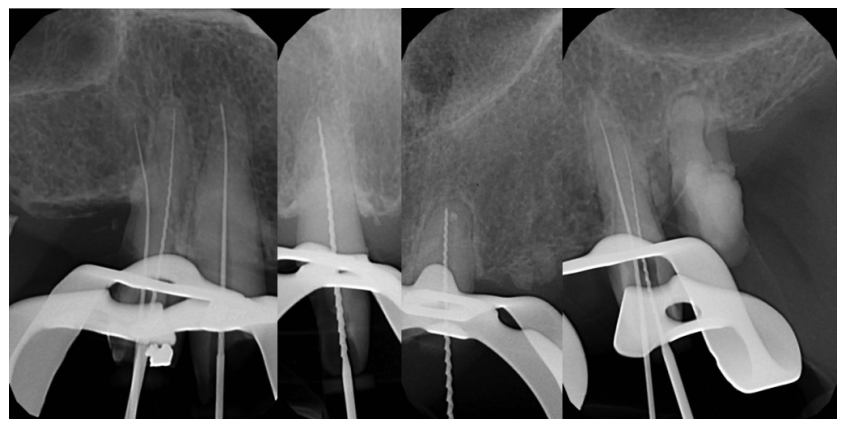

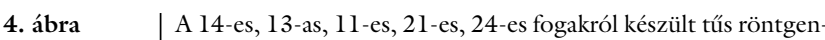
kontrollfelvétel

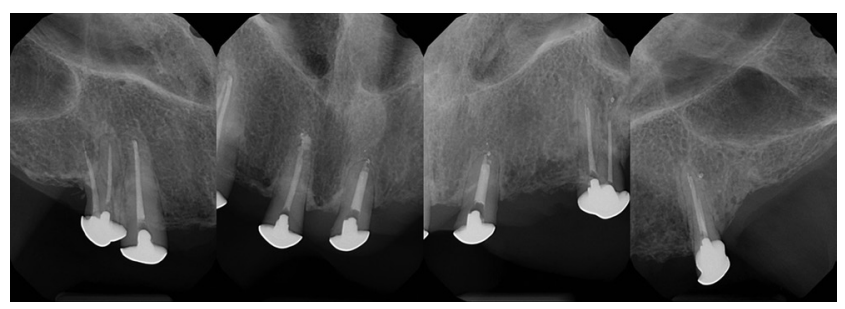

5. ábra $\mid$ Az elkészült gyökértömés látható a 14-es, 13-as, 11-es, 21-es és 24-es fogban, csapos sapkás ellátás mellett

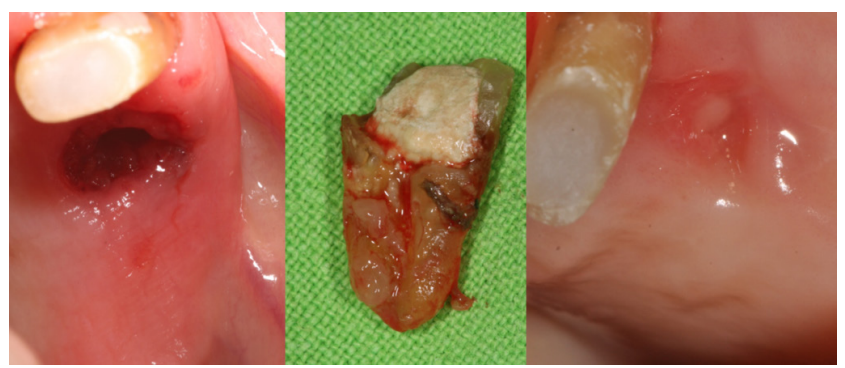

6. ábra

| A 25-ös radix látható eltávolítás előtt-után és a gyógyult seb

Hollandia) használatával (5. ábra). A 24-es fog palatinalis gyökércsatornájába a gyökérkezelés során egy 15\# Haedström reszelő beletörött. A betört eszközt nem lehetett eltávolítani, de el lehetett haladni mellette, így a fogat megtartottuk.

A gyökérkezeléseket követően a paroendodontalis laesio miatt menthetetlen 25-ös fog antibiotikumvédelemben eltávolításra került (6. ábra). A fogeltávolítás előtti héten, majd azt követően két hétig Soós és mtsai javaslata alapján klórhexidines öblögetést javasoltunk [26].

A felső állcsontban elhelyezkedő, panaszmentes, gyökértömött gyökereket funkcionálisan nem lehetett helyreállítani, ezért nem építettük fel azokat, csupán csapos fémsapkával fedtük le. Egyéni kanál készítéséhez kétfázisú, egyidejű precíziós szituációs lenyomatot vettünk (Zetaplus-Oranwash L; Zhermack, Badia Polesine, Olaszország) Unicast lenyomatvételi stiftek segítségével. $\mathrm{Az}$ alsó állcsontról egyéni kanál készítéséhez alginát (Tropicalgin; Zhermack) szituációs lenyomatvétel történt fogatlan állcsontra alkalmas gyári lenyomatkanál segítségével. 


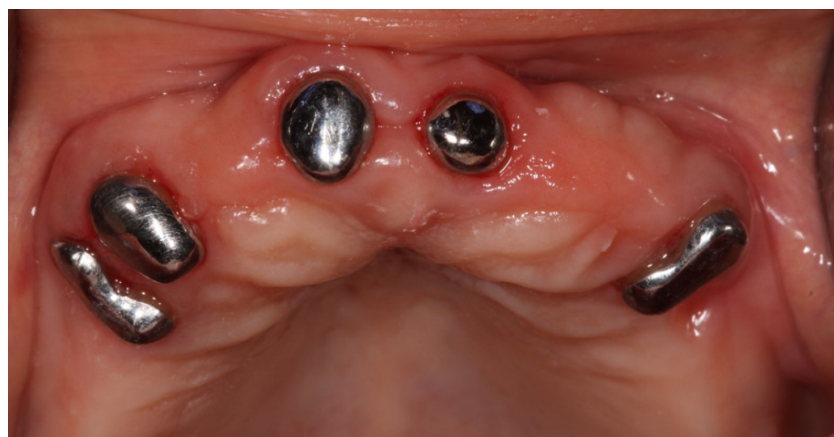

7. ábra

A felső állcsont képe a 14-es, 13-as, 11-es, 21-es és 24-es fogak csapos sapkás lezárását követően

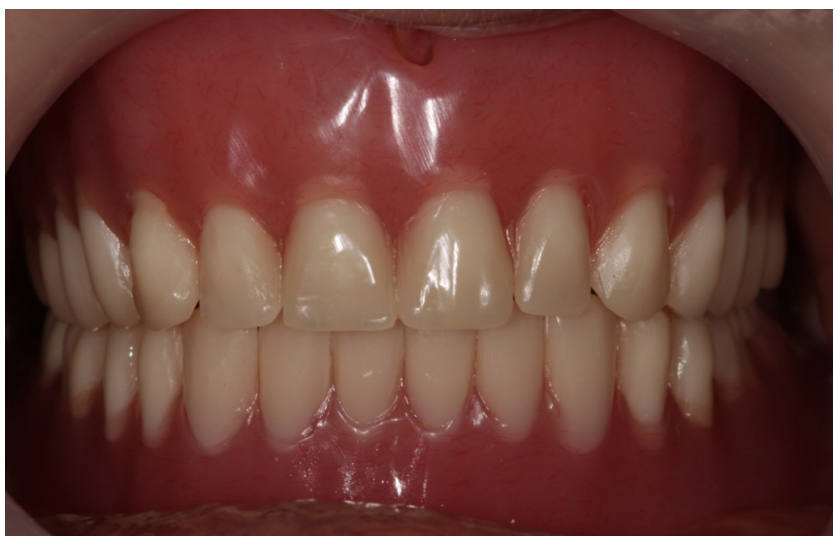

8. ábra

| Az elkészült fogmú a szájba próbálás és beartikulálás után

A csapos sapkák beragasztása után (Ketac ${ }^{\mathrm{TM}} \mathrm{Cem} ; 3 \mathrm{M}$ ESPE) (7. ábra) a funkcionált egyéni lenyomatkanalakkal funkciós lenyomatvétel következett mindkét állcsontról cink-oxid-eugenol lenyomatanyaggal (SS White; Lavadent, London, Egyesült Királyság).

A harapási sablonok a funkciós lenyomatról kiöntött mintán érkeztek, a centrális okklúzió meghatározása ezek segítségével történt. A fogpróba során a spatulapróba negatív volt. A billentőerők kiküszöbölése céljából kétoldali kiegyensúlyozott artikulációban kértük a fogsort. Készre vitelnél a labortól igényeltük a nyálkahártya felé tekintő felszínek körültekintő polírozását, csökkentve a nyálkahártya-trauma veszélyét. A kész fogsor szájban történt ellenőrzésekor a statikus és mozgások közbeni stabilitást megfigyelve módosításra nem volt szükség (8. ábra).

Egynapos, 1 hetes, 1, 3, 6, 12, 24 hónapos kontrollokon a páciens megjelent. A fogsoron történó igazításokat a fogtechnikai labor segítségével végeztük, törekedve a polírozottság megtartására. Röntgenkontrollon elváltozás nem volt látható. Két évvel a fogpótlás átadása után a páciens panaszmentes.

\section{Következtetés}

A biszfoszfonátok gátolják a csont átépülését, immunhomeosztázisát, angiogenezisét és mucotoxicusak, ezért a
MRONJ kialakulásában meghatározó etiológiai tényezők. Az antireszorptív készítmények alkalmazása azonban bizonyos betegségekben nem kerülhető el. Körültekintéssel végzett gondos fogorvosi szanálást igényelnek tehát azok a páciensek, akik antireszorptív terápia előtt állnak. Azokban az esetekben, amikor a kezelés már folyamatban van, de még necrosis nem alakult ki az állcsontokban (rizikópáciensek csoportja), jól meggondolt prevenciós elveken alapuló kezelési tervet kell felállítani antibiotikum adásával szinkronizálva. A patogén szájflórát minden beavatkozás előtt antiszeptikus szájöblítők használatával csökkenteni kell. Ennek már az otthoni szájhigiéné megfelelő kialakítása is fontos lépése.

A magas MRONJ-rizikójú betegek esetén a fogak megtartása az elsődleges cél, még akkor is, ha esztétikailag és funkcionálisan nem állíthatók helyre. Habár a gyökérkezelés biztonságosabbnak tûnik a necrosis kialakulásának veszélyére nézve, mint a foghúzás, ez a beavatkozás is vezethet MRONJ kialakulásához [27]. A bacteriaemia lehetősége miatt a gyökérkezelések során a munkahossz meghatározásáig antibiotikumprofilaxis javasolt. Sebészi beavatkozás esetén pedig antibiotikumvédelemben és minimálinvazív módon kell eljárni. Moinzadeh és mtsai ajánlása szerint a nem sebészi endodontiai beavatkozásokat is kimagasló körültekintéssel kell elvégezni [28]. A Kofferdam kapocs felhelyezését is supragingivalisan kell elvégezni, csökkentve az íny mikrotraumái kialakulásának veszélyét [28].

A fogpótlások tervezésekor fontos figyelembe venni a páciensek habitusát, egészségi állapotát. Az esetismertetésben meghatározó tényező volt a páciens látási nehézsége és rossz kézügyessége. A fogpótlás egyszerűségére kellett törekedni. A kivehető fogpótlás nyálkahártya felé néző felszínének maximális felpolírozásával, bilaterálisan balanszírozott okklúzióval és gyakori kontrollal a nyálkahártyán esetlegesen kialakuló mikro- és makrotraumákat ki lehet védeni, illetve a MRONJ-t korai stádiumban fel lehet ismerni.

Odafigyeléssel az antireszorptív kezelésben részesülő pácienseknél a MRONJ kialakulásának veszélyét akár 73\%-kal sikerülhet csökkenteni [29]. Nem lehet eléggé hangsúlyozni az antireszorptív és antiangiogenikus terápia megkezdése előtti fogászati szanálás fontosságát [30]. Sajnos ma Magyarországon ez még nem rutinszerú eljárás. A terápia ideje alatt az osteonecrosis kialakulásának valószínúségét a gondos anamnézisfelvétellel, a rizikópáciens felismerésével, prevencióval és folyamatos kontrollal mérsékelhetjük a legfőképpen.

Anyagi támogatás: A közlemény megírása anyagi támogatásban nem részesült.

Szerzöi munkamegosztás: B. Zs.: A szakirodalom gyưjtése, kezelési terv, betegellátás, referálás. V. Sz. E.: A szakirodalmi háttér áttekintése alapján a kezelési terv egyeztetése, szövegkorrektúra. T. Zs.: A publikáció alap- 
koncepciójának megfogalmazása, szakmai irányítás, korrektúra. A cikk végleges változatát valamennyi szerző elolvasta és jóváhagyta.

Érdekeltségek: A szerzőknek nincsenek érdekeltségeik.

\section{Irodalom}

[1] Ruggiero SL, Dodson TB, Fantasia J, et al. American Association of Oral and Maxillofacial Surgeons position paper on medication-related osteonecrosis of the jaw - 2014 update. J Oral Maxillofac Surg. 2014; 72; 1938-1956.

[2] Baron R, Ferrari S, Russell RG. Denosumab and bisphosphonates: different mechanisms of action and effects. Bone 2011; 48: 677-692.

[3] Wood J, Bonjean K, Ruetz S, et al. Novel antiangiogenic effects of the bisphosphonate compound zoledronic acid. J Pharmacol Exp Ther. 2002; 302: 1055-1061.

[4] Reid IR, Bolland MJ, Grey AB. Is bisphosphonate-associated osteonecrosis of the jaw caused by soft tissue toxicity? Bone 2007; 41: 318-320.

[5] Aguirre JI, Akhter MP, Kimmel DB, et al. Oncologic doses of zoledronic acid induce osteonecrosis of the jaw-like lesions in rice rats (Oryzomys palustris) with periodontitis. J Bone Miner Res. 2012; 27: 2130-2143.

[6] Boonyapakorn T, Schirmer I, Reichart PA, et al. Bisphosphonate-induced osteonecrosis of the jaws: prospective study of 80 patients with multiple myeloma and other malignancies. Oral Oncol. 2008; 44: 857-869.

[7] Marx RE. Pamidronate (Aredia) and zoledronate (Zometa) in duced avascular necrosis of the jaws: a growing epidemic. J Oral Maxillofac Surg. 2003; 61: 1115-1117.

[8] Palaska PK, Cartsos V, Zavras AI. Bisphosphonates and time to osteonecrosis development. Oncologist 2009; 14: 1154-1166.

[9] King AE, Umland EM. Osteonecrosis of the jaw in patients receiving intravenous or oral bisphosphonates. Pharmacotherapy 2008; 28: 667-677

[10] Hoff AO, Toth BB, Altundag K, et al. Frequency and risk factors associated with osteonecrosis of the jaw in cancer patients treated with intravenous bisphosphonates. J Bone Miner Res. 2008; 23: 826-836.

[11] Bamias A, Kastritis E, Bamia C, et al. Osteonecrosis of the jaw in cancer after treatment with bisphosphonates: incidence and risk factors. J Clin Oncol. 2005; 23: 8580-8587.

[12] Marx RE, Sawatari Y, Fortin M, et al. Bisphosphonate-induced exposed bone (osteonecrosis/osteopetrosis) of the jaws: risk factors, recognition, prevention, and treatment. J Oral Maxillofac Surg. 2005; 63: 1567-1575.

[13] Ferraz CC, Gomes NV, Gomes BP, et al. Apical extrusion of debris and irrigants using two hand and three engine-driven instrumentation techniques. Int Endodontic J. 2001; 34: 354-358.

[14] Russmueller G, Seemann R, Weiss K, et al. The association of medication-related osteonecrosis of the jaw with Actinomyces spp. infection. Sci Rep. 2016; 6: 31604.

[15] Association of Hungarian Medical Societies (MOTESZ) Prevention and treatment of bisphosphonate-induced jaw bone osteonecrosis, II. [MOTESZ. A biszfoszfonátok által indukált áll- csontnekrózisok megelőzése és kezelése II.] Fogorv Szle. 2014; 107: 106-109. [Hungarian]

[16] Starck WJ, Epker BN. Failure of osseointegrated dental implants after diphosphonate therapy for osteoporosis: a case report. Int J Oral Maxillofac Implants 1995; 10: 74-78.

[17] Kawano F, Tada N, Nagao K, et al. The influence of soft lining materials on pressure distribution. J Prosthet Dent. 1991; 65: 567-575.

[18] Taguchi N, Murata H, Hamada T, et al. Effect of viscoelastic properties of resilient denture liners on pressures under dentures. J Oral Rehabil. 2001; 28: 1003-1008.

[19] Okita N, Orstavik D, Orstavik J, et al. In vivo and in vitro studies on soft denture materials: microbial adhesion and tests for antibacterial activity. Dent Mater. 1991; 7: 155-160.

[20] Pinto JR, Mesquita MF, Henriques GE, et al. Effect of thermocycling on bond strength and elasticity of 4 longterm soft denture liners. J Prosthet Dent. 2002; 88: 516-521.

[21] Kulak-Ozkan Y, Sertgoz A, Gedik H. Effect of thermocycling on tensile bond strength of six silicone-based, resilient denture liners. J Prosthet Dent. 2003; 89: 303-310.

[22] Ghapanchi J, Lavaee F, Moattari A, et al. The antibacterial effect of four mouthwashes against Streptococcus mutans and Escherichia coli. J Pak Med Assoc. 2015; 65: 350-353.

[23] Cousido MC, Tomas Carmona I, Garcia-Caballero L, et al. In vivo substantivity of $0.12 \%$ and $0.2 \%$ chlorhexidine mouthrinses on salivary bacteria. Clin Oral Investig. 2010; 14: 397-402.

[24] Gallego L, Junquera L, Pelaz A, et al. Rubber dam clamp trauma during endodontic treatment: a risk factor of bisphosphonaterelated osteonecrosis of the jaw? J Oral Maxillofac Surg. 2011; 69: 93-95.

[25] Peters LB, van Winkelhoff AJ, Buijs JF, et al. Effects of instrumentation, irrigation and dressing with calcium hydroxide on infection in pulpless teeth with periapical bone lesions. Int Endodontic J. 2002; 35: 13-21.

[26] Soós B, Vajta L, Szalma J. Sunitinib and zoledronic acid induced osteonecrosis of the jaw. Case report. [Sunitinib és zolendronsav által indukált állcsont-osteonecrosis.] Orv Hetil. 2015; 156: 1865-1870. [Hungarian]

[27] Ruggiero, SL, Dodson TB, Assael LA, et al. American Association of Oral and Maxillofacial Surgeons position paper on bisphosphonate-related osteonecrosis of the jaws -2009 update. J Oral and Maxillofac Surg. 2009; 67: 2-12.

[28] Moinzadeh AT, Shemesh H, Neirynck NA, et al. Bisphosphonates and their clinical implications in endodontic therapy. Int Endod J. 2013; 46: 391-398.

[29] Kyrgidis A, Vahtsevanos K, Koloutsos G, et al. Bisphosphonaterelated osteonecrosis of the jaws: a case-control study of risk factors in breast cancer patients. J Clin Oncol. 2008; 26: 46344638 .

[30] Varga G, Mikala G, Váróczy L, et al. Management of multiple myeloma in Hungary in 2016. [A myeloma multiplex megközelítése Magyarországon 2016-ban.] Orv Hetil. 2016; 157: 123-137. [Hungarian]

(Bata Zsófia dr., Budapest, Páva utca 17. 2/3., 1094 e-mail: batazsofia@gmail.com) 